\title{
Development of paddy stripper header mechanism
}

\section{G.B. BHANAGE, P.U. SHAHARE, V.V. AWARE AND J.S. DEKHALE}

Received : 28.02.2017; Revised : 19.03.2017; Accepted : 27.03.2017

See end of the Paper for authors' affiliation

Correspondence to :

\section{G.B. BHANAGE}

Department of Farm Machinery and Power College of Agricultural Engineering and Technology, Dr. B.S. Konkan Krishi Vidyapeeth, Dapholi, RATNAGIRI (M.S.) INDIA

Email : gbhanage1588@gmail. com
ABSTRACT : Stripping is the process of removing the seeds from the plant and straw remained anchored to the soil. The main advantages of stripping is the increasing capacity of the combine harvester with reduced amount of material other than grain ratio (MOG) and power requirement for threshing and cleaning which promotes to develop small and light weight mechanism suitable for small and fragmented land. A laboratory stripper header mechanism (SHM) was developed for stripping paddy grains and collecting them in grain tank. It consisted of stripping rotor, stripping elements, hood, frame and grain tank. Two profiles of stripping elements viz., slender arrow head (A) and spaced slender arrow head (B) of stripping elements were used. The performance of the developed SHM was evaluated on specially developed test rig to study the effect of two levels of forward speed (1.65 and $2.25 \mathrm{~km} / \mathrm{h}$ ) and four levels of peripheral speed (16.95, 19.78, 22.6 and 25.45 $\mathrm{m} / \mathrm{s}$ ) on shattered and un-stripped grain loss was studied. It consisted of track, platform and crop holders. SHM was stationary and platform was movable on track. Minimum shattered grain loss of 5.78 per cent was obtained with stripping element A at $2.25 \mathrm{~km} / \mathrm{h}$ forward speed and at $19.78 \mathrm{~m} / \mathrm{s}$ peripheral speed. Minimum un-stripped grain loss of 0.84 per cent was obtained with stripping element $A$ at $2.25 \mathrm{~km} / \mathrm{h}$ forward speed and $25.45 \mathrm{~m} / \mathrm{s}$ peripheral speed. The performance of the slender arrow head stripping element was found to be better as compared to spaced slender arrow head.

- KEY WORDS : Paddy, Stripping, Stripping element, Test rig, Grain loss

-HOW TO CITE THIS PAPER : Bhanage, G.B., Shahare, P.U., Aware, V.V. and Dekhale, J.S. (2017). Development of paddy stripper header mechanism. Internat. J. Agric. Engg., 10(1) : 179-185, DOI: 10.15740/HAS/IJAE/10.1/179-185. 